\section{Coal comfort for Britain?}

\author{
Allan Piper reports on the fortunes of the British coal industry, \\ reflected in the recent controversial decision to develop the \\ Selby coalfield
}

\begin{abstract}
DERHAPS the most important point to be made about the plans to open up the Selby coalfield is that just three years ago any idea that the National Coal Board (NCB) might invest up to $£ 400$ milions in a single new venture would probably have been dismissed as economically senseless. In steady decline since the $1950 \mathrm{~s}$, the industry seemed by 1973 to be plunging inexorably to extinction, pulled by the ever tightening purse strings of successive governments intractably committed to oil and nuclear power by the strategy laid down in a 1967 White Paper on Fuel Policy. But the hiccough that arrived with the Arab oil crisis forced another look at the shape of coal's future-and the Selby project has become, perhaps deceptively, the banner heading coal's march back to prominence in Britain's energy strategy.
\end{abstract}

If all goes according to plan, the first Selby coal will arrive at the surface within four years, and by 1985 the new field should provide 10 million tons annually. But while the Selby scheme is ambitious enough itself, its real significance lies in its role as part of a wider "Plan for Coal" developed to boost sagging production levels over the next ten years. Quick to realise the opportunities presented by the fuel price adjustments of recent years, the NCB along with government and union officials formulated the ten year plan back in 1974 in an effort to stabilise and expand the British coal industry.

The aim is to introduce 42 million tons of new capacity by 1985 , thus outstripping the decline of exhausted reserves and boosting production from last year's 125 million tons to an annual level of 150 million tons. Though almost half, and possibly more, of the new capacity is expected from new mines such as those on the Selby field, an equally significant amount will be brought out from pits now scheduled for extension and modernisation. And with exploration programmes proving around 500 million tons of new workable deposits each year (some even as far south as the edge of the London Basin), supplies look safe for at least another century at existing extraction rates.

In support of the expansion drive, the NCB has already begun stepping up its programme to introduce new mining equipment and techniques, and mining research is now firmly focused on the underground machinery. Initial estimates put the necessary research and development expenditure at $£ 33$ millions up to 1980. The increase in mechanisation will not see a reduction in the existing work force: the NCB view is that recruitment must average around 28,000 a year $-8,000$ a year more than during the cutbacks of the last decade-just to stabilise output levels. By the time target levels are achieved in the mid-1980s the industry should maintain a stable work-force of 250,000 , with a hoped-for productivity growth in excess of $4 \%$ a year.

The massive investment programme at the heart of the ten year plan was 1974 prices, a figure which included $£ 600$ millions in new investment. These figures are already being revised to $£ 1,800-£ 2,000$ millions and $£ 1,000$ millions respectively because of inflation, and the NCB might even be looking for special subsidies in the future if it cannot raise the money itself. Significantly, though, the coal industry was one of the few areas to escape the heavy spending cuts announced in a recent White Paper on Public Expenditure; NCB borrowing powers have been extended from $£ 700$ millions to $£ 1,100$ millions under the National Coal Board (Finance) Act, and a further increase to $£ 1,400$ millions awaits House of Commons approval. The NCB has also received strong European support through its membership of the European Coal and Steel Community (ECSC). Since Britain joined the EEC in 1973, the Community has approved loans for the NCB totalling $£ 143$ millions.

While the new flow of cash is crucial to the revitalisation of the industry, the UK Energy Secretary, Mr Anthony Wedgwood Benn, has not been unmindful of the need for comfortable unionmanagement relationships. He admitted that union thinking influenced his recent decision to reappoint Sir Derek Ezra as NCB Chairman when his present term ends in July, and actually published the text of a letter seeking union advice on new appointments. Ezra is regarded favourably by the unions within the industry; his period of office has so far spanned two major national coal strikes, but he has managed to remain on consistently good terms with them. Last year a deficit development of remotely controlled put at an estimated $£ 1,400$ millions at

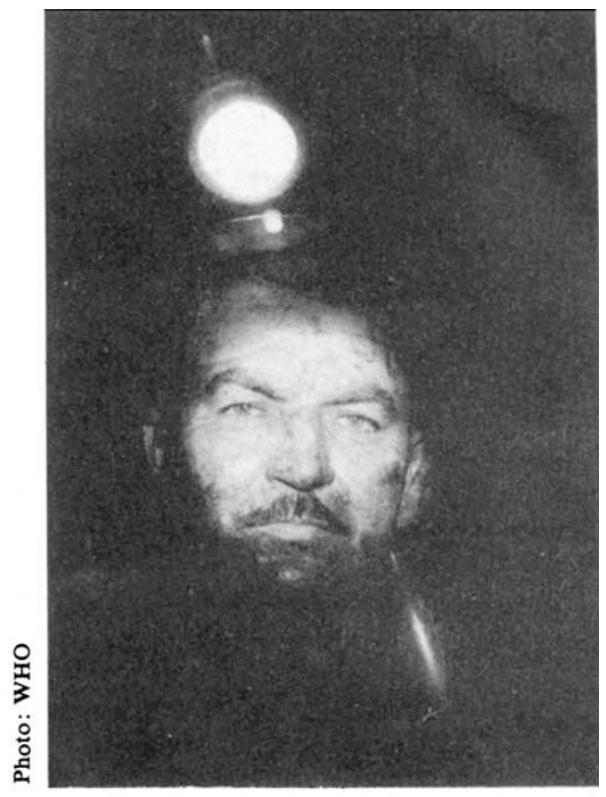

\section{Coal face}

of $£ 112$ millions was turned round to a profit of $£ 34$ millions, and last week Ezra gave estimates that the NCB broke even in 1975-76. His new term will run to 1979 , by which time the ten year plan will be well under way.

All of which seems encouraging enough. Certainly with such key issues as finance and industrial relations apparently resolved, the coal industry is anticipating a rosy future, with coal occupying a central role in any long term energy strategy. The large demands of the British steel industry are expected to rise with the next economic upturn, and recent progress in the development of high-grade coking coal may curb future demands for imports. Even more important to the NCB is the judgment that by the mid-1980s nuclear and natural gas resources can between them fulfill considerably less than half of Britain's annual energy requirements of between 400 and 500 million tons coal equivalent. And while much of the shortfall, which could be as high as 370 million tons coal equivalent, will be met by indigenous and imported oil, competitive coal prices, the NCB argues, should ensure demands for its entire output, particularly as cheap imported coal is expected to have become unavailable.

But whether or not that prognosis holds true hinges largely upon the NCB's largest single customer, the Central Electricity Generating Board (CEGB), which last year burned 67 million tons of NCB coal in its power stations (alongside which the South of Scotland Electricity Board consumed a further 4 million tons). And here the critical problem arises. The CEGB is showing a marked reluctance to commit itself to coal-fuelled generating power while oil, gas and nuclear options remain available. One reason seems to 
be concern at the NCB's record of efficiency. But another is escalating price rises. The NCB, as a member of the ECSC, remains unfettered by national pricing policy, and over the past two years coal prices have rocketed by an alarming $170 \%$; the latest $15 \%$ increase adds an estimated $£ 150$ millions to the CEGB fuel bill, pushing it up to a colossal $£ 1,600$ millions a year. The CEGB chairman, Arthur Hawkins, was sharply critical : "The coal board", he said at a February meeting with Ezra, "might at least have invited its biggest customer to discuss at the highest level the serious implications of the increase, not only for electricity but for coal's prospects in the power station fuel market".

Although taking the point, Ezra's difficulty is that his hands are virtually tied. Confronted with powerful unions, the NCB finds almost half of its production costs are wage bills, while over half of present annual production is won unprofitably from older pits, using outdated machinery and production methods. The increasing volume of reserve stocks piling up at pitheads and power stations around the country adds to the problem: reserves are now standing at 30 million tons, worth $£ 500$ millions in realisable income, and costing the coal board $£ 3$ a ton in interest on borrowed capital each year. Last year excess sales over running production reduced the stockpiles by less than $10 \%$, but it is a measure of the severity of the situation that before the NCB borrowing ceiling was raised last month, requirements rose above the earlier limit by $£ 75$ millions, an excess that had to be provided from government contingency funds.

Success for the NCB plan, then, is to an important extent contingent upon CEGB agreement to convert oil and gas-fired power stations to coal. In proposing an 11 million ton increase in coal burning by the CEGB over the next two years, Ezra has pointed out that a switch from oil and gas to coal could save the electricity industry $£ 3$ to $£ 4$ on each ton of fuel, and the country $£ 250$ millions on the balance of payments. The idea reportedly has the backing of the Department of Energy, but Hawkins has dismissed it as "quite ridiculous" at a time of expenditure cutbacks in the nationalised industries and falling consumer demand (which last year dropped by an estimated $5 \%$ ). Further, aside from conversion costs, Hawkins has also to consider the heavy national investment in North Sea oil and gas.

As for the less immediate outlook, NCB hopes are similarly overshadowed by CEGB reluctance to order new coalfuelled power plant. Though the coalfired, 2,000 MW installation at Drax in
Yorkshire has just reached completion, 5 of the 12 remaining installations still under construction in Britain are nuclear powered, and 6 are oil-fired; only the $1,500 \mathrm{MW}$ Aberthaw $B$ in South Wales, due on-line around the end of the decade, is designed to burn coal. In addition, CEGB last month announced that forward ordering plans, already unlikely to favour the NCB, may well be revised downwards following the most recent demand forecasts. These indicate that consumer demand for the winter of 1982--83 will not rise above a peak of $52,000 \mathrm{MW}$, a surprising 2,000 MW down on last year's forecast for 1981-82, and only around $25 \%$ -or $3.5 \%$ a year-over current demands.

The CEGB has nonetheless made a couple of moves towards raising its requirement for NCB coal. Imports, which last year totalled 4.5 million tons, are to be cut. Hawkins recently announced that import contracts undertaken during 1973-74 to offset the then prevailing shortage of British reserves are to be run down over the next financial year. And CEGB demand for British coal last year topped the previous year's level by 3 million tons, while oil consumption was cut by almost a third to only 14 million tons coal equivalent. This turn-round indicates that if the price, quality and demand is right, the CEGB's 111 coalfired installations could burn more coal than at present-in fact the requirement could rise as high as 90 milfion tons of coal a year, a figure more compatible with the aims of the ten year plan than the existing level of $67 \mathrm{mil}$ lion tons. The present shortfall occurs simply because demand levels above the early morning baseline of $22,000 \mathrm{MW}$ are now met by oil-fired generating power in preference to coal power. But once the Plan for Coal gathers sufficient momentum, increasing productivity and cutting production costs, the NCB could swing that method of priority operation to its own advan- tage, leapfrogging coal-fired generating power above the oil and nuclear options.

Should that possibility not prove successful, export markets offer little prospect of an easy solution to the glut. In north-western Europe, the only realistic potential outlet, British coal will face competition not only from low-priced North American exports, but also from Polish coal maintained at continually depressed "administered prices" which undercut competition.

The $£ 400$ millions Selby project, however, in keeping with the optimistic front it presents to the outside world, remains for the most part unscathed by the wider complications, though critics of the ten year plan may disagree. The Main Barnsley Seam, stretching for 110 square miles beneath the Vale of York and an amenable three or so metres thick, will provide almost half of the new annual output by the mid-1980s. Geological conditions are sufficiently favourable to allow extraction using "drift mining" techniques, involving production through a single sloping tunnel rather than multiple vertical shafts. Production is expected to begin within four years, and when full operational capacity is achieved by the mid-1980s a maximum of 52,000 tons of coal a day will travel by conveyor to the surface, providing the nearby coal-fired power stations at Drax, Eggborough and Ferrybridge with continuous fuel supplies by rail.

Ezra says Selby will produce "the coal which, with North Sea oil and gas, is going to make Britain the only main nation in Europe which will be selfsufficient in energy by the mid-1980s". With the NCB also engaged on large research programmes in pyrolosis and liquefaction techniques, and British and European research efforts continuing in the areas of fluidised bed combustion and coal gasification, the future does seem promising. But there are still uncertainties to be removed if the turnround is to materialise.

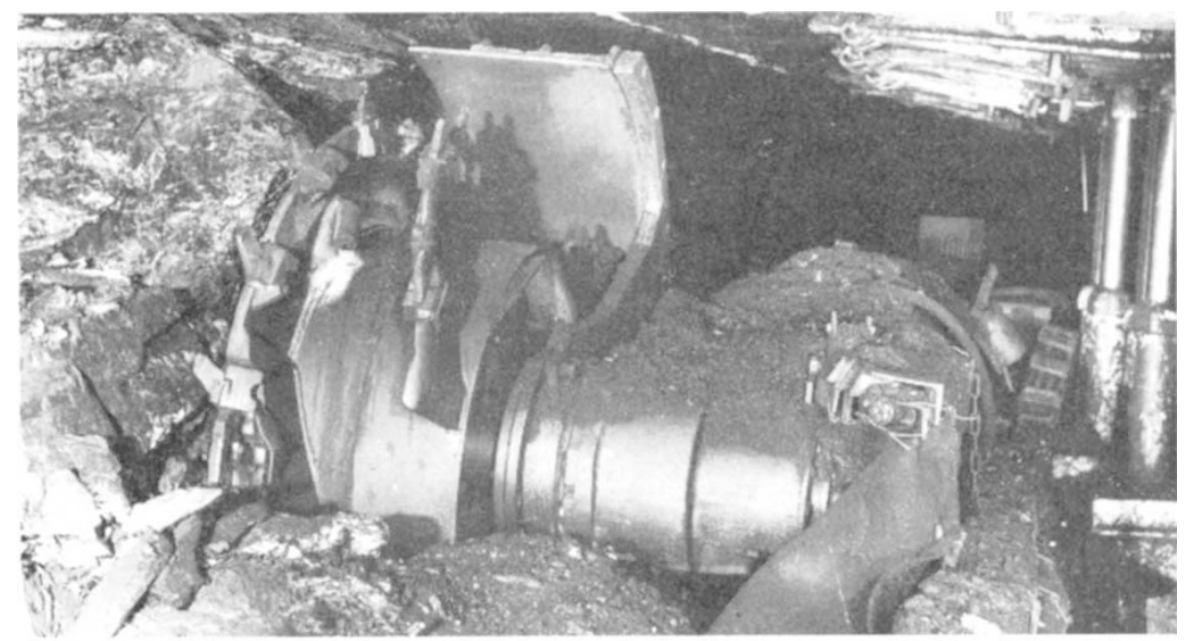

Coal cutting machine 